\title{
Quality of life in chronic venous patients who do or do not wear compressive stockings
}

\author{
Qualidade de vida em doentes venosos crônicos usuários \\ e não usuários de meias elásticas
}

Bruno Vieira Melo ${ }^{1}$, Priscilla Gabriela Moreira Dantas Tojal', Flávia de Jesus Leal', Renata Cardoso Couto

\begin{abstract}
Background: Wearing elastic compression stockings is of considerable significance for patients with chronic venous disease (CVD), since their physiological effect is to improve venous hemodynamic parameters, making them a good treatment option that can impact on patients' quality of life. Objective: To assess quality of life in patients with chronic venous disease who do or do not wear elastic stockings. Methods: This was a cross-sectional observational study assessing a sample of $50 \mathrm{CVD}$ patients of both sexes, divided into two groups, one who wear elastic stockings and another who do not. Primary variables were the domains of the SF-36 (Medical Outcomes Study Short-form 36) and AVVQ (Aberdeen Varicose Veins Questionnaire) and secondary variables were: age; sex; physical activity; educational level; profession; wearing elastic stockings (frequency, pressure and type); elevation of lower limbs; itching and CEAP classification. The SF-36 and AVVQ quality of life questionnaires were administered to patients. Statistical significance was set at $p<0.05$. Results: Wearing elastic stockings proved beneficial for the quality of life of people with chronic venous disease. For the AVVQ disease-specific questionnaire the greatest improvements were in overall score $(p=0.0028)$ and the extent of varicosity domain $(p=0.000)$. The SF-36 domains role emotional $(p=0.017)$ and functional capacity $(p=0.000)$ both improved. Conclusions: Wearing elastic stockings is an effective treatment for CVD that improves disease-specific quality of life and also leads to improvements in general quality of life. Keywords: quality of life; compression stockings; venous insufficiency.
\end{abstract}

\section{Resumo}

Contexto: $\mathrm{O}$ uso de Meias Elásticas Compressivas em pacientes com doença venosa crônica (DVC) é de grande significância, na medida em que reflete, na sua atuação fisiológica, melhora nos padrões hemodinâmicos venosos, configurando-se como boa opção terapêutica e podendo interferir na qualidade de vida do indivíduo. Objetivo: Avaliar a qualidade de vida de indivíduos com doença venosa crônica usuários e não usuários de meias elásticas. Métodos: Trata-se de um estudo observacional de corte transversal, no qual foram avaliados 50 pacientes de ambos os sexos, com DVC, compondo dois grupos: um de usuários e o outro, de não usuários de meias elásticas. Teve, como variáveis primárias, os domínios dos questionários SF-36 (Medical Outcomes Study Short-form 36) e AVVQ (Aberdeen Varicose Veins Questionnaire); constituíram as variáveis secundárias: idade; sexo; atividade física; escolaridade; profissão; uso de meias elásticas (frequência de uso, pressão e tipo); elevação de membros inferiores; presença de prurido, e CEAP. Os pacientes responderam aos questionários de qualidade de vida SF-36 e AVVQ. A significância estatística considerada foi p<0,05. Resultados: A utilização da meia elástica mostrou benefício na qualidade de vida dos indivíduos portadores de doença venosa crônica. O aspecto mais favorecido no questionário específico AVVQ relacionou-se à sua pontuação total $(p=0,0028)$ e ao domínio Extensão da varicosidade $(p=0,000)$. Já quanto ao $S F-36$, podem-se apontar o aspecto emocional $(p=0,017)$ e a capacidade funcional $(p=0,000)$. Conclusão: $O$ uso de meias elásticas apresenta-se como uma terapêutica eficaz na DVC, melhorando a qualidade de vida específica e havendo, também, ganho na qualidade de vida geral. Palavras-chave: qualidade de vida; meias de compressão; insuficiência venosa.

\footnotetext{
${ }^{1}$ Universidade Estadual de Ciências da Saúde de Alagoas - UNCISAL, Maceió, AL, Brazil. Financial support: None.

Conflicts of interest: No conflicts of interest declared concerning the publication of this article. Submitted: September 11, 2014. Accepted: September 24, 2014.
}

The study was carried out at Clínica Escola de Fisioterapia Dra. Delza Gitaí, Universidade Estadual de Ciências da Saúde de Alagoas (UNCISAL), Maceió, AL, Brazil. 


\section{INTRODUCTION}

The beneficial effect of wearing elastic compression stockings on the quality of life (QoL) of patients with chronic venous disease (CVD) is very significant, since the result of their physiological action is improvement in venous hemodynamic parameters, which in turn means that they are a good treatment option. ${ }^{1}$

Even though the effect of compression stockings disappears completely within 24 hours of removing them, ${ }^{2}$ compression therapy provokes a partial regression of the to the vein wall abnormalities, reduces the diameter of veins, draws the valve leaves closer together, suppressing or attenuating reflux, and also reduces venous pressure; and, as such, reduces symptomology and improves the QoL of CVD patients. ${ }^{3}$

Quality of Life is a subjective concept that involves self-perception and is made up of several different elements (which may be positive, negative or bidirectional), such as physical function and emotional and social wellbeing, and its detailed and careful assessment is considered a very important factor is assessing the impact of chronic diseases such as CVD on the daily lives of the population., The negative point of CVD in QoL is most related to the domains of pain, physical function, mobility and psychological state, with reports of depression and social isolation as expressions of CVD; these are common at advanced stages of the disease, causing a direct impact on quality of life, which is inferior in these patients. ${ }^{5,6}$

There are many definitions of quality of life and there are also several different ways of measuring it. However, the key idea that must be implicit and which underlies this study is attention to QoL from the perspective of CVD, and a realistic assessment of the implications of the disease for daily life, taking into consideration physical, social and psychological aspects. $^{7}$

This is a significant disease that can cause serious socioeconomic problems. Chronic venous disease is defined as dysfunction of the venous system due to venous hypertension, caused by valve incompetence and/or obstruction of venous flow. It can be congenital or acquired and can affect the superficial and deep vein systems. Diagnosis is made on the basis of clinical features and the results of supplementary tests and treatment can include elastic bindings or stockings, specific dressings and surgical procedures. ${ }^{1,3,4,7,8}$
Chronic venous disease is a generalized manifestation in the population of the Western world. Estimates of the prevalence of varicose veins vary considerably in response to variations in several different aspects: the study population, its age, gender, and ethnicity, measurement methods and the definition used for the disease itself. As a result, estimates range from 2 to $56 \%$ of male individuals and from 1 to $60 \%$ of females.

For many of these patients with CVD, elastic stockings are a good treatment option, but there is a lack of research into the subject and a very small number of studies have been published on the effects of wearing elastic stockings on quality of life of patients with CVD. It is therefore necessary to answer the following research question: how is the QoL of individuals with CVD who do and do not wear compression stockings?

\section{MATERIALS AND METHODS}

This study was approved by the Research Ethics Committee under protocol No. 2036, in accordance with National Health Council regulations (National Health Council (Conselho Nacional de Saúde)) contained in CNS Resolution 196/96 dealing with research involving human beings.

This was a cross-sectional observational study. The sampling technique employed was non-probabilistic. The majority of subjects were recruited at a project set up to care for venous disease patients and additional patients registered with other healthcare projects that also treat patients with the disease were also enrolled. Patients who met the inclusion and exclusion criteria attended an initial interview.

Individuals of both sexes aged 18 years or over and who had CVD were enrolled. Demographic data were collected first and then lower limbs were examined. All limbs were examined by visual inspection in the orthostatic position by the same trained and qualified examiner who classified the limbs according to CVD severity using the clinical manifestations scale of the internationally accepted CEAP classification (C1-C4). Where the patient had CVD involving both lower limbs, the higher CEAP (clinical) score was used for analysis.

The CEAP Classification is a system that was proposed in 1995 to classify vascular disease on the basis of clinical manifestations, etiologic factors, anatomic distribution and pathophysiology. The system has been employed in countless vascular studies in order to classify CVD clinical presentation and to measure changes in disease severity. The 
clinical scale contains the following grades: $\mathrm{C} 0$ - no visible or palpable signs of venous disease. $\mathrm{C} 1$ - telangiectasies or reticular veins, $\mathrm{C} 2$ - varicose veins, C3 - edema, C4 for skin conditions such as hyperpigmentation and lipodermatosclerosis, C5 - healed venous ulcer, and C6 - active venous ulcer. $^{9}$

Individuals were excluded if they also presented with any of the following conditions: arterial or lymphatic abnormalities; diabetes; hypertension; neuropathy; erysipelas, lymphangitis, acute deep vein thrombosis, ulcer of non-venous origin, psychiatric disorders and/or dementia (physician-diagnosed), as were individuals over the age of 60 with cognitive abnormalities, according to the Mini Mental State Examination (MEEM).

The primary variables investigated in this study are the domains of the SF-36 (Medical Outcomes study short-form 36) and the AVVQ- Brazil (Aberdeen Varicose Veins Questionnaire - version Brazil). Secondary variables are as follows: age; sex; physical activity; educational level; profession; use of elastic stockings (frequency with which worn, pressure exerted and type); lower limb elevation, presence of itching and CEAP score.

The SF-36 is a multidimensional, generic, quality-of-life questionnaire that has been validated for Brazil, comprising 36 items distributed across eight domains (functional capacity; role physical; pain; general health; vitality; social functioning; role emotional, and mental health). The overall score ranges from 0 to 100 , where zero corresponds to the worst general health status and 100 to the best health status. ${ }^{10}$

The AVVQ-Brazil questionnaire contains 13 questions (items) that evaluate the quality of life of people with lower limb venous disease and also their disease severity. Items are distributed across four domains: pain and dysfunction; esthetic appearance; extent of varicosity, and complications. The result is interpreted along a scale from zero to 100 , with zero representing the best score (no evidence of the disease) and 100 the worst (greatest disease severity). ${ }^{9,11}$

The study sample comprised 50 patients divided into two groups: 25 patients who wore elastic stockings and 25 who did not wear them, all distributed from CEAP grades $\mathrm{C} 1$ to $\mathrm{C} 4$.

At first contact, patients who met the inclusion and exclusion criteria were provided with information about the study and asked to sign a free and informed consent form. Once patients had duly understood the study and agreed to take part in it, they were given instructions on how to complete the SF-36 and AVVQ-Brazil questionnaires.

If patients were functionally illiterate all the questionnaires were read to them out loud by the researcher, rigorously following the instructions provided by the author of the AVVQ, provided in the form of an interview script that includes a fixed way of asking questions and without interfering with the process of replying to the questions.

Statistical analysis was conducted without masking of items. Calculations were conducted with the aid of Microsoft Excel (Microsoft Excel 2003 for Windows, Microsoft Inc., Redmond, WA) and SPSS (Statistical Package for Social Sciences), version 17.0.

The Shapiro-Wilk test of normality was applied and it was found that none of the AVVQ domains and only the domains pain, general health and mental health from the SF-36 exhibited normal distributions. In view of this, the Mann-Whitney nonparametric test was used for comparisons between groups. Student's $t$ test was used for the other domains of the SF-36. Alpha $(\alpha)$ values greater than or equal to 0.05 were used as the cutoff for rejection of the null hypothesis in statistical tests. For all tests the significance level adopted was 5\% (0.05).

\section{RESULTS}

Data were collected on a total of 50 patients with ages ranging from 22 to 80 years, with a mean of $50.3( \pm 14.8)$ years. Just 5 patients $(10 \%)$ were male and $45(90 \%)$ were female. The CEAP grades were distributed as follows: C1- 13 (26\%); C2- 11 (22\%); C3- 15 (30\%), and C4- 11 (22\%). There was no sample deviation.

The majority of these individuals - 35 (70\%) - had spent 9 years or more in education and $38(76 \%)$ of the entire sample did not engage in physical activity. With relation to profession, $13(26 \%)$ were retired; nine $(18 \%)$ were domestic workers; six $(12 \%)$ were housewives; three $(6 \%)$ were public employees, and three $(6 \%)$ had other professions.

Four of the five male patients $(80 \%)$ wore elastic stockings, while $21(46.6 \%)$ of the 45 females in the sample wore them. As such, $25(50 \%)$ people in the sample wore elastic stockings every day, $15(60 \%)$ of whom elevated lower limbs before putting on stockings and felt itching before or after wearing them. The most common pressure used by wearers was $20 / 30 \mathrm{mmHg}$, worn by $23(92 \%)$ individuals, and $21(84 \%)$ individuals wore three-quarter length stockings. 
With regard to specific quality of life, there were significant statistical differences between patients who wore and patients who did not wear elastic stockings for total score on the AVVQ-Brazil scale and for its Extent of Varicosity domain. There were no significant differences for the other domains $(\mathrm{p}<0.05)$ (Table 1).

Patients who did not wear elastic stockings scored a mean of 28.8 points on the total AVVQ-Brazil score, whereas those who did wear stockings scored a mean of 22.0 points. Mean score for extent of varicosity among individuals who did not wear elastic stockings was 44.0, compared to a mean score of 20.8 points for patients who did wear them $(\mathrm{p}<0.05)$. It is therefore demonstrated that the elastic stockings wearers had better quality of life than non-wearers in these domains (Table 1).

With regard to the results for the general quality of life questionnaire, there were significant statistical differences between elastic stocking wearers and non-wearers for the domains Functional Capacity and Role Emotional on the SF-36 ( $\mathrm{p}<0.05)$ (Table 2).

Individuals who did not wear stockings had a mean Functional Capacity score of 13 points, whereas those who did wear them scored a mean of 38 points, which indicates better quality of for stocking wearers in this domain than for non-wearers. For Role Emotional, patients who did not wear stockings scored a mean of 48.5 points, whereas those who did wear them scored a mean of 63.5 points, indicating that wearing stockings also conferred better quality of life in emotional terms. There were no significant differences in the other domains ( $\mathrm{p}>0.05$ ) (Table 2).

\section{DISCUSSION}

Chronic venous disease is a severe public health problem with higher prevalence among females ${ }^{12}$ and people in their third decade of life (31-40 years). ${ }^{13}$ the findings of this study agree in terms of sex, since $90 \%$ of patients were female, but mean age was higher, since the mean age of patients fell within the fifth decade, at 50.3 years.

Additionally, the sample included $76 \%$ of sedentary individuals of both sexes, which contrasts with a study by Bertoldi et al., ${ }^{14}$ that analyzed 4,030 university employees, finding a $47.8 \%$ prevalence of inactivity among males and 59.2\% among females.

The majority of the sample had not completed primary education, which is similar to some other studies that have also observed that individuals with CVD had low educational levels, ${ }^{14,15}$ with a predominance of patients who had not studied beyond primary education among females and of functionally illiterate males, which can have an impact on their understanding of measures necessary to care for their own health. ${ }^{13,14}$

Table 1. Mean AVVQ scores by group (patients who do or do not wear compression stockings) and by domain

\begin{tabular}{|c|c|c|c|c|c|}
\hline & & SW & & W & $\mathrm{p}^{*}$ \\
\hline DOMAINS & $M$ & SD & M & SD & \\
\hline AVVQ SCORE & 28.8 & 12.4 & 22.00 & 11.5 & 0.028 \\
\hline Pain and Dysfunction & 32.8 & 26.0 & 24.6 & 23.1 & 0.224 \\
\hline Esthetic Appearance & 59.1 & 35.7 & 53.0 & 30.7 & 0.416 \\
\hline Extent of varicosity & 44.0 & 12.9 & 20.8 & 12.6 & 0.000 \\
\hline Complications & 9.7 & 11.0 & 9.8 & 15.5 & 0.652 \\
\hline
\end{tabular}

*Statistical significance $(\mathrm{p}<0.05)$. NCSW: Not compression stocking wearers. CSW: Compression stocking wearers. M: Mean. SD: Standard deviation.

Table 2. Mean SF-36 scores by group (patients who do or do not wear compression stockings) and by domain.

\begin{tabular}{lccccc}
\hline \multicolumn{1}{c}{ DOMAINS } & NCSW & \multicolumn{3}{c}{ CSW } & $\mathrm{p}^{*}$ \\
\hline Functional capacity & M & SD & M & SD & 0.000 \\
Role Physical & 13.0 & 7.4 & 38.0 & 7.4 & 0.270 \\
Pain & 49.8 & 29.3 & 58.2 & 23.6 & 0.207 \\
General Health & 42.0 & 43.1 & 57.0 & 41.8 & 0.059 \\
Vitality & 73.8 & 9.2 & 79.0 & 11.8 & 0.170 \\
Role Social & 60.2 & 24.2 & 68.7 & 18.7 & 0.439 \\
Emotional Functioning & 56.2 & 19.2 & 60.6 & 20.6 & 0.017 \\
Mental Health & 48.5 & 22.3 & 63.5 & 39.7 & 0.647 \\
\hline
\end{tabular}

*Statistical significance $(\mathrm{p}<0.05)$. NCSW: Not compression stocking wearers.CSW: Compression stocking wearers. M: Mean. SD: Standard deviation. 
Quality of life questionnaires can reveal aspects that are not mentioned by patients and can indicate factors that should receive greater attention. ${ }^{16,17}$ According to a study published by Smith et al., ${ }^{18}$ combining the AVVQ with the SF-36 provides a more effective measurement of quality of life among patients with varicose veins and these data were an important factor in the choice of which questionnaires to employ in this study.

Figueiredo et al..$^{19}$ employed air plethysmography before and after use of elastic stockings to assess 29 limbs from 16 CVD patients and concluded that elastic stockings were effective for improving venous volume, venous filling index, ejection fraction and residual volume fraction, primarily exhibiting beneficial effects during the period when patients were wearing the elastic stockings. In this study patients who wore elastic stockings exhibited benefits in the item extent of varicosity, which adds further weight to the importance of elastic stockings for quality of life.

Another study compared quality-of-life during preoperative and postoperative periods for 145 patients with symptomatic venous disease using the AVVQ and the SF-36 before and after treatment, demonstrating a trend towards higher scores in the functional capacity domain during the postoperative period. This study therefore concluded that treatment of venous disease can improve quality of life. ${ }^{20}$ In this study there was a statistically significant difference in the functional capacity domain, thereby showing that wearing elastic stockings is an effective treatment that improves quality of life, in agreement with the study published by Klem et al. ${ }^{20}$

Studies have shown a significant association between Quality of Life and CVD and, employing the SF-36, it has been found that even in the early phases this disease has a substantial impact on the physical dimensions of health, manifest as functional limitations and difficulties with daily activities. ${ }^{21}$ The findings of the present study show a significant difference in the SF-36 functional capacity domain with patients who wore elastic stockings scoring higher than those who did not, indicating better quality of life with relation to this domain.

A study conducted to determine the prevalence and severity of CVD, also employing the SF-36, concluded that CVD negatively impacted quality of life in $3.3 \%$ of the men and $8.4 \%$ of the women in the sample. ${ }^{22}$ This is in agreement with the present study, in which it was found that patients who do not wear elastic stockings had worse quality of life than those who did wear them, notwithstanding the fact that the majority of those who did wear them did not have excellent quality of life.

Chronic venous disease can significantly reduce quality-of-life of people who are affected by it and causes psychological effects such as sadness, depression, irritability, worries about the appearance and social isolation. ${ }^{4,13,23}$ Franks et al. ${ }^{24}$ Administered the Nottingham Health Profile (NHP), which assesses emotional, social and physical problems, and found that the parameters physical activity, social activity, pain and mental health were all improved by compression therapy. In this study, patients who did not wear compressive stockings scored lower on average in the role emotional domain than wearers, indicating that wearing stockings confers better quality of life with relation to this aspect.

Elastic stocking therapy is considered the best treatment option for venous insufficiency and can be considered the first choice treatment. ${ }^{25}$ Notwithstanding, further studies are needed that explore the correlations between wearing stockings and quality-of-life, primarily employing the AVVQ, which is a recently-validated questionnaire that has been adapted to the Brazilian setting.

It is important to point out that the fact that this is one of the first studies to be conducted in Brazil utilizing the AVVQ questionnaire and so there are few other studies available in the literature with which to enrich the information available.

\section{CONCLUSIONS}

Wearing elastic stockings is an effective treatment for CVD that improves disease-specific quality of life, particularly in the item Extent of Varicosity, and also offers gains in general quality of life and in the functional and emotional domains.

\section{REFERENCES}

1. Angélico RCP. Úlcera venosa crônica: qualidade da assistência e o conhecimento sobre o direito a saúde. Natal: Programa de Pósgraduação em Enfermagem, Universidade Federal do Rio Grande do Norte; 2010

2. Figueiredo MAM, Filho AD, Cabral ALS. Avaliação do efeito da meia elástica na hemodinâmica venosa dos membros inferiores de pacientes com insuficiência venosa crônica. J Vasc Bras 2004;3(3):231-7.

3. França LHG, Tavares V. Insuficiência venosa crônica: uma atualização. J Vasc Bras. 2003;2(4):318-28.

4. Moura RMF, Gonçalves GS, Navarro TP, Britto RR, Dias RC. Correlação entre classificação clínica CEAP e qualidade de vida na doença venosa crônica. Rev Bras de Fisioter. 2010;14(2):99-105 http://dx.doi.org/10.1590/S1413-35552010005000007. 
5. Longo Jr O, Buzatto SHG, Fontes AO, Miyazaki COM, Godoy JMP. Qualidade de vida em pacientes com insuficiência arterial crônica em membros inferiores. Revista da SBACV-RJ. 2002; 11(1).

6. Santos RFFN, Porfírio GJM, Pitta GBB. A diferença na qualidade de vida de pacientes com doença venosa crônica de leve e grave. J Vasc Bras. 2009;8(2):143-7. http://dx.doi.org/10.1590/ S1677-54492009000200008.

7. Leal J, Mansilha A. Como avaliar o impacto da doença venosa crônica na qualidade de vida. Angiologia e Cirurgia Vascular. 2010;6(4):173-87.

8. Lima RCM, Santiago L, Moura RMF, Filaretti FAS, Souza CSA, Evangelista SSM, et al. Efeitos do fortalecimento muscular da panturrilha na hemodinâmica venosa e na qualidade de vida em um portador de insuficiência venosa crônica. J Vasc Bras. 2002;1(3):219-26.

9. Leal FJ. Validação no Brasil de questionário de qualidade de vida na doença venosa (AVVQ - Brasil) [dissertação]. São Paulo: Programa de Pós-graduação em Saúde Coletiva, Escola Paulista de Medicina, Universidade Federal de São Paulo; 2012.

10. Ciconelli RM, Ferraz MB, Santos W, Meinão I, Quaresma MR. Tradução para a língua portuguesa e validação do questionário genérico de avaliação de qualidade de vida SF-36 (Brasil SF-36). Rev Bras Reumatol. 1999;39(3):143-50.

11. Leal FJ, Couto RC, Pitta GBB, Leite PTF, Costa LM, Higino WJF, et al. Tradução e adaptação cultural do Questionário Aberdeen para Veias Varicosas. J Vasc Bras. 2012;11(1):34-42. http://dx.doi. org/10.1590/S1677-54492012000100007.

12. Castro e Silva M, Cabral ALS, Barros N, Castro AA, Santos MERC. Diagnóstico e tratamento da doença venosa crônica. Normas de orientação clínica da Sociedade Brasileira de Angiologia e Cirurgia Vascular (SBACV). J Vasc Bras. 2005;4(Suppl 2):S185-94.

13. Costa LM, Higino WJF, Leal FJ, Couto RC. Perfil clínico e sociodemográfico dos portadores de doença venosa crônica atendidos em centros de saúde de Maceió (AL), Brasil. J Vasc Bras. 2012;11(2):108-13. http://dx.doi.org/10.1590/ S1677-54492012000200007.

14. Bertoldi CML, Proença RPC. Doença venosa e sua relação com as condições de trabalho no setor de produção de refeições. Rev Nutr. 2008;21(4):447-54. http://dx.doi.org/10.1590/ S1415-52732008000400009.

15. Moura RGF. Funcionalidade e qualidade de vida em idosos com doença venosa crônica [doutorado]. Belo Horizonte: Programa de Pós- Graduação em Ciências da Reabilitação, Escola de Educação Física, Fisioterapia e Terapia Ocupacional., Universidade Federal de Minas Gerais; 2010.

16. Gonçalves FDP, Marinho PEM, Maciel MA, Galindo Filho VC, Dornelas AA. Avaliação da qualidade de vida pós-cirurgia cardíaca na fase I da reabilitação através de questionário MOS SF-36. Rev Bras Fisioter. 2006;10(1):121-6. http://dx.doi.org/10.1590/ S1413-35552006000100016.

17. Tarlov AR, Ware JE Jr, Greenfield S, Nelson EC, Perrin E, Zubkoff $M$. The Medical Outcomes Study. An application of methods for monitoring the results of medical care. JAMA. 1989;262(7):92530. http://dx.doi.org/10.1001/jama.1989.03430070073033. PMid:2754793

18. Smith JJ, Garratt AM, Guest M, Greenhalgh RM, Davies AH. Evaluating and improving health-related quality of life in patients with varicose veins. J Vasc Surg. 1999;30(4):710-9. http://dx.doi. org/10.1016/S0741-5214(99)70110-2. PMid:10514210
19. Figueiredo $M$, Simão PP, Pereira BMA, Penha-Silva N. Eficácia da compressão pneumática intermitente (CPI) nos membros inferiores sobre o fluxo sanguíneo das veias femorais comuns. J Vasc Bras. 2008;7(4):321-4. http://dx.doi.org/10.1590/ S1677-54492008000400006.

20. Klem TM, Sybrandy JE, Wittens $\mathrm{CH}$. Measurement of healthrelated quality of life with the Dutch translated Aberdeen Varicose Vein Questionnaire before and after treatment. Eur J Vasc Endovasc Surg. 2009;37(4):470-6. http://dx.doi.org/10.1016/j. ejvs.2008.11.036. PMid:19117775

21 Kaplan RM, Criqui MH, Denenberg JO, Bergan J, Fronek A. Quality of life in patients with chronic venous disease: San Diego population study. J Vasc S. 2003;37(5):1047-53.

22. Rabe E, Pannier F. What have we learned from the Bonn Vein Study? Phlebolymphology. 2006;13(4):188-94.

23. Macedo EAB, Oliveira AKA, Melo GSM, Nobrega WG, Costa IK, Dantas DV, et al. Caracterização sócio-demográfica dos pacientes com úlcera venosa atendidos em um hospital universitário. Rev Enferm UFPE. 2010; 4(Suppl):1863-7.

24. Franks PJ, Bosanquet N, Brown D, Straub J, Harper DR, Ruckley CV. Perceived health in a randomised trial of single and multilayer bandaging for chronic venous ulceration. Phlebology. 1995; (Suppl 1):17-9.

25. Figueiredo $M$. A terapia da compressão e sua evidência científica. J Vasc Bras. 2009;8(2):100-2.

Correspondence Bruno Vieira Melo

Rua Prefeito Pedro Gaia, 1048, Camoxinga CEP 57500-000 - Santana do Ipanema (AL), Brazi

Tel.: + 55 (82) 9994-3547

E-mail: brunop_melo@hotmail.com

Author information BVM has a bachelor's degree in Physical Therapy from Universidade Estadual de Ciências da Saúde de Alagoas (UNCISAL).

PGMDT has a bachelor's degree in Physical Therapy from Universidade Estadual de Ciências da Saúde de Alagoas (UNCISAL). FJL is a physical therapist, MSc in Sciences from Universidade Federal de São Paulo (UNIFESP); Assistant professor at Universidade Estadual de Ciências da Saúde de Alagoas (UNCISAL)

RCC is a physical therapist, MSc in Sciences from Universidade Federal de São Paulo (UNIFESP); Assistant professor at Universidade Estadual de Ciências da Saúde de Alagoas (UNCISAL).

Author contributions Conception and design: BVM, PGMDT, FJL Analysis and interpretation: BVM, PGMDT, FJL, RCC Data collection: BVM, PGMDT, FJL Writing the article: BVM, PGMDT, FJL

Critical revision of the article: FJL, RCC Final approval of the article*: BVM, PGMDT, FJL, RCC Statistical analysis: BVM, PGMDT, FJL, RCC Overall responsibility: FJL

*All authors have read and approved of the final version of the article submitted to I Vasc Bras. 